\title{
ANALYSIS OF THE ENVIRONMENTAL EFFECTS OF ENERGY LINES (ARTVIN ORTAKÖY FOREST MANAGEMENT CASE)
}

\author{
Hilal SURAT ${ }^{1 *}$, Bülent Zeki SURAT ${ }^{2}$ \\ 1*Artvin Coruh University, Faculty of Art and Design, Department of Landscape Architecture, Artvin, Turkey; \\ ${ }^{2}$ Artvin Forest Regional Directorate, Arhavi Forest Management Center Chief, Artvin, Turkey; \\ *Corresponding Author Hilal SURAT, e-mail: hilal881@artvin.edu.tr; bulentzekisurat@ogm.gov.tr;
}

Received October 2019; November 2019; Published December 2019;

DOI: https://doi.org/10.31407/ijees9429

\begin{abstract}
In the present study, the environmental impacts of $154 \mathrm{Kw}$ Meydanc1k Bayram HPP-Artvin II Power Transmission Line located within the borders of Ortaköy Forest Management Directorate under Artvin Forest Management Directorate were investigated. Review of the situation analysis results conducted to investigate the effects of wood extraction and the construction of transmission lines demonstrated that the most significant impact of logging was due to the random release of excavated soil on the slopes and resulting destruction of land structure and the flora. Review of the effects of wood extraction demonstrated that the most significant factor was the increase of fungus and insect damages in trees injured in the process. Review of the effects that could be observed during and after the construction of the transmission lines demonstrated that the most significant impact was on human and wildlife health due to the proximity of transmission lines to the settlements and negative impacts of electromagnetic fields on the health of the organisms inhabiting the area.
\end{abstract}

Key words: Energy Transmission Line, Ecological Structure, Environmental Impact, SWOT Analysis, Artvin 